\title{
Positive Duties and Human Rights: Challenges, Opportunities and Conceptual Necessities
}

\author{
Hugh Breakey \\ Griffith University
}

Can human rights impose positive duties to act, as well as negative duties constraining action? At first glance there seem to be strong reasons for wishing human rights could impose positive duties - such reasons include the promotion of welfare rights and the positive protection of liberty rights (e.g. police protection against assault). However, any attempt to construct rights-based positive duties threatens to dissolve hallmark features of rights. In this article the duty-properties possessed by uncontroversial rights-based negative duties are comprehensively analysed. Drawing on this analysis, a range of key properties is developed, including 'regime-level right-holder universality' and 'manyto-one directedness', as well as a 'centres of pressure' vision of rights, by which it is argued that positive duties can accord with the keystone commitments of rights-based moral theories. In so doing, a conceptual space for rights-based positive duties is defended.

Keywords: human rights; natural rights; positive duties; imperfect duties; welfare rights

Positive duties oblige duty-bearers to actively perform actions or pursue goals. Such duties differ from negative duties, which prohibit actions ('thou shalt not ...'). Rights-based positive duties comprise a subset of positive duties more generally. For ease, when I refer to 'positive duties' in this article, I mean rights-based positive duties, though of course many will agree there are positive duties based on other moral grounds, such as personal virtue.

Positive duties based on human rights pose a dilemma. On the one hand, they seem a sensible way to respect, promote and facilitate human rights. On the other hand, rightsbased conceptual arguments against positive duties can appear compelling.

In the literature on each side of this argument, different camps often talk past one another. Given that positive duties have myriad properties (ten, at my count) about which a rights theorist can have justifiable qualms, arguments in favour of positive duties can fail to consider the full gamut of challenges facing them. ${ }^{1}$ Equally, however, those arguing against rights-based positive duties often proceed too swiftly, confidently declaring supposed conceptual necessities about rights-based duties, and using these putative necessities to reject positive rights-based duties (Frederick, 2010; Nozick, 1974, pp. 28-9). For example, Onora O'Neill (2005, pp. 427-31; 2010, pp. 167-8) castigates the very idea of rights without determinate duty-holders. How can Alf hold a right to health care (say) unless at least one specific person (a physician, presumably) holds a correlative duty to treat him? Rights against harm, in contrast, have determinate duty-holders. We all obey a universal obligation not to assault Alf. But this tactic will not work for rights to health care; everyone cannot bear a duty to heal Alf. Since we cannot universally allocate positive duties to provide goods and services, O'Neill (2005, p. 430) charges such duties must remain un-allocated, threatening welfare rights with being 'null and void, indeed undefined'. O'Neill thus isolates specific properties (properties I will later term 'duty-bearer

Political Studies Association
(C) 2014 The Author. Political Studies published by John Wiley \& Sons Ltd on behalf of Political Studies Association. This is an open access article under the terms of the Creative Commons Attribution License, which permits use, distribution and reproduction in any medium, provided the original work is properly cited. 
universality' and 'duty-right sufficiency') attached to well-accepted rights-based duties and determines they should be present in all rights-based duties. She then completes the argument by showing that positive duties supporting welfare rights cannot possess these vital properties.

Against the critics, but taking seriously the extensive challenges they lay down, in this article I vindicate the possibility of rights-based positive duties by exhaustively describing all the relevant properties of uncontroversial rights-based negative duties and arguing that positive duties can, through the adoption of key properties I develop below, successfully capture what is essential in these properties.

Before embarking on the argument, allow me to clarify some terminology and sketch two reasons why a rights theory might avail itself of positive duties. For our purposes here, 'human rights' refers to key interests or freedoms of a human being that just on their own demand respect from all other people. Like the natural rights of the early Enlightenment liberals (e.g. John Locke), these entitlements command respect even in the state of nature, where there is no state authority to enforce them. Contemporary rights theorists such as Jeremy Waldron, Amartya Sen, Henry Shue and James Griffin employ this broad notion of human rights, and it accords with the notion of rights captured by the Universal Declaration of Human Rights (UDHR). This notion of human rights differs, on the one hand, from the purely legal notion of human rights found in international human rights law, ${ }^{2}$ and on the other hand, from 'political' conceptions of human rights - as they arise, for example, in the work of John Rawls (1999) - where rights are constructions of the constitutional or discursive processes of specific political communities.

I will refer to the object protected by the right as an 'interest'. But the object of protection may be a freedom or capacity, a need, or an aspect of a person's welfare or personhood (Griffin, 2008; Sen, 2004; Shue, 1980; 1988). Note also I want to keep it as an open question at the outset whether all the duties corresponding to the right must be legal duties. This is one of the questions the following analysis aims to answer rather than a premise from which it begins.

So conceived, we can divide human rights into negative rights (e.g. against assault and theft) and positive rights (e.g. to education). Complicatedly, protecting negative rights requires performing positive duties (Shue, 1980, pp. 37-40). For example, a police officer might need to apprehend Aneka (a positive action) to stop her from assaulting Ahmed (violating his negative rights). To avoid confusing talk of positive duties based on negative rights, I will refer to negative rights as 'liberty rights' and positive rights as 'welfare rights' thereby confining my use of 'positive' and 'negative' terms exclusively to duties.

Using this terminology, then, we can locate two reasons why human rights might ground positive duties. First, we need positive protection to secure people's liberty rights (as we just saw with Aneka and Ahmed). Protecting people's liberty rights against assault and theft requires police forces, judiciaries, prison systems and defence forces. These institutions require positive actions and contributions. ${ }^{3}$ If respect for rights justifies these minimal-state institutions it presumably justifies the positive contributions such institutions require. Second, an optimal theory of rights might include welfare rights, such as the rights to education and health care laid down in the UDHR. Since these welfare rights require substantial resources, they must be capable of imposing positive duties. Such rights might 
be justified on their own terms or they might be argued to derive from the same ethical fundaments as liberty rights.

These two reasons show how positive duties can potentially contribute to both liberty rights and welfare rights. However, they will count for little if rights theories simply lack the conceptual space to incorporate positive duties. This article aims to show that rights theories have that space.

\section{Properties of a Signature Rights-based Duty}

This section catalogues the properties of an uncontroversial rights-based duty - namely the negative duty correlating with the liberty right to bodily security. Anybody who accepts any sorts of rights at all, I think, will accept this familiar rights-based duty: 'Each and every person has a legal duty owed to every other person not to physically assault that person.' A particular instance of this duty is: 'Aneka owes a legal duty to Ahmed not to assault him.' You might think Aneka's rights-based duty here seems straightforward enough. In fact, however, it houses a wealth of subtle and complex properties. Aneka's duty is:

1 Duty-bearer determinate: The duty-bearer required to perform the act (Aneka) is determinate.

2 Right-holder determinate: The beneficiary of the act (Ahmed) is determinate.

3 Duty-bearer universal: The duties corresponding to Ahmed's right are universally imposed on everyone (more carefully, on all mature, sane humans). Everyone who can respect his right must respect his right.

4 Right-holder universal: Every single person is the subject of such duties, and holds the resultant entitlements.

5 Perfect: There is no latitude for discretion in when, how, where and toward whom the duty should be performed.

6 Negative: Aneka's duty is a prohibition on action - a 'side constraint' on acting.

7 Legal: Aneka is legally accountable to others for the performance of her duty in the sense that others may be entitled to compel her compliance and that her nonperformance renders her liable for coercive punishment (by an appropriate authority).

7a Retributive apt: A potential, derivative property is that Aneka's failure to perform the duty creates a positive moral reason for imposing coercive punishment on Aneka.

8 Duty-right sufficient: If every duty holder (e.g. Aneka) performs their duties, every right-holder (e.g. Ahmed) will necessarily have their rights fulfilled. The duty-bearer's duties suffice to secure the right-holders' entitlements.

9 Directed: The duty is owed by Aneka to Ahmed, and similarly for every other duty-bearer-right-holder dyad. (Contrast this with Aneka owing the duty to herself or God.) If Aneka fails to perform her duty, then, (a) a wrong has been done to Ahmed in particular, and (b) this wrong has been done by Aneka in particular.

9a Remedial apt: A potential, derivative property is that if Aneka fails to perform her duty, then, because she owed its performance to Ahmed, she can be required to offer apology and compensation to him.

10 Consistent: Aneka's duty can be assimilated alongside her other rights-based duties, without clashes. Because this property refers to all the other duties in the rights 
regime, consistency is a systemic quality and can be evaluated only when we have complete information about those duties. Even so, some duties are more apt to create conflicts than others. Arguably, Aneka's negative duty not to assault Ahmed has a high propensity for consistency.

11 Reciprocal: Ahmed owes to Aneka exactly the same rights-based duty that Aneka owes to him.

12 Deontological: Aneka's duty is to not assault Ahmed herself, rather than to ensure the overall minimisation of assaults on Ahmed - e.g. by third parties. (More on this complex property below.)

Now the question at the heart of our enquiry arises: Which of these 12 dutyproperties are necessary requirements of a rights-based duty? We can imagine rightsbased positive duties possessing almost none of these properties. For example, Bill might be aware that people in refugee camps in foreign countries are vulnerable to assault. Morally concerned about these rights violations, and in a position to respond, Bill decides he is duty-bound to contribute money to UNHCR. The duty Bill recognises appears to be responding to his respect for others' rights. But the duty is not right-holder determinate or directed: Bill does not owe the duty to a specific person, even if a given person (e.g. Buhjah) eventually benefits. The duty is not legal: Bill will not be punished for not performing it. The duty is not perfect: Bill might have responded in other ways, such as by lobbying his country to contribute to peacekeeping. The duty does not possess duty-bearer universality: others who are less well off than Bill need not contribute. Finally, the duty's status as deontological or reciprocal is murky, as is whether it possesses duty-right sufficiency. Given that Bill's duty possesses few of the signature properties of Aneka's quintessential rights-based duty, is it really rights-based? Or does the lack of these properties conceptually foreclose the existence of any such rights-based duty?

\section{Which Duty-properties are Conceptually Necessary?}

If we wish to determine which properties are conceptually necessary for a rights-based duty, we first need to work out what we mean by 'conceptually necessary'. The question is not, I submit, a definitional one. Because of the ambiguity bedevilling the term 'right' in its many usages (lay, philosophical and legal), we aren't helped by assertions that rights by definition must correlate with (say) legal duties. Counter-examples to any proposed definition could be multiplied at will.

Rather than being definitional, the substantive issue lies in the fact that rights theories enjoy particular sorts of advantages over rival theories - features distinguishing rights theories from purely deontological theories, on the one hand, and from consequentialist theories, on the other. These may be deep-theoretical advantages, or more applied ones (e.g. that the theory's prescriptions match people's considered judgements). I am not asserting here the philosophical superiority of rights theory over its rivals - merely that each ethical-political theory has its own attractions. If the addition of positive duties to the rights theory collapses it into a type of consequentialism, for example, then a lynchpin feature of the rights theory has been lost. 
Consider Property 4 above: right-holder universality. If the duties corresponding to a right do not possess right-holder universality then only some people enjoy the right correlating with the duty. But a basic feature of human rights is precisely that all human beings hold them. If we strip right-holder universality from rights-based duties, then we threaten to divest rights theory of one of its flagship attractions.

Let's call the properties right-based duties must possess for the over-arching rights theory to retain its signature attractions 'essential duty-properties'. Our first task, then, requires determining which duty-properties count as essential. Taking the list of dutyproperties canvassed in the previous section as a point of departure, we will begin with a list of ten prima facie plausible 'essential duty-property' candidates. Examination will reveal that many of these candidates turn out not to be essential duty-properties, but that they facilitate deeper properties that are themselves essential. Having isolated an essential duty-property, our second order of business requires evaluating whether positive duties can possess that property. Ultimately, I will argue that all of the essential duty-properties can be possessed by (suitably structured) positive duties.

As we proceed, I conjure up several specific examples of positive duties, for example, Cho's obligation to support his daughter Chitra, and Dinesh's duty to rescue a drowning stranger, Daria. I do not mean to contend that our best theory of human rights would include these duties. Rather, our question is whether there are any rights-based reasons categorically precluding them. Naturally, opening a conceptual space for a duty does not positively justify its existence.

\section{Negativity}

Negativity is the duty-property of being a side constraint on action, rather than a positive requirement to perform some action. There seems little reason to consider this dutyproperty conceptually necessary per se. However, it may be (as we will see) that negativity implicates deeper properties such as 'deontological,' 'duty-bearer universality' and 'consistency'. As such, the need for this duty-property hinges on the forthcoming assessment of those other properties. To anticipate, the duty-property of deontology prioritises duties not to harm. As such, we can expect every right to at least include negative duties prohibiting certain harms to its protected interest. However, this does not preclude positive duties also being used to promote the interest.

\section{Legal Accountability}

Legal accountability means that an authority may compel compliance with the duty, or punish those who don't perform it. Rights theories prize legal accountability for two reasons. First, making duty-bearers legally accountable for failing in their duties increases the sense in which rights can be guaranteed to the right-holders - that is, the likelihood that the right will be fulfilled, and for right-holders to be able to rely on this fact. Since fallible human agents can always fail in their duties, rights regimes can never provide ironclad guarantees. Still, by removing impunity, legal accountability improves guarantees. Second, legal accountability authorises an (arguably) appropriate retributive response to the profound moral wrongfulness of violating others' rights. 
At best, however, these considerations only require that some of the duties based on the right must possess legal accountability. With respect to guarantees, coercive avenues may be just one part of a range of strategies employed to guarantee rights. Legal accountability, at best, merely expresses a state's commitment to produce a result, which is not at all the same thing as producing that result (Schmidtz and Brennan, 2010, p. 9). Equally, state enforcement of a right might transgress other rights; consider the intrusions into privacy required for policing promissory rights to marital fidelity.

With respect to retribution, even if the profound wrongdoing inherent in direct assaults on rights cries out for coercive punishment, the non-performance of other rights-based duties may not imply the same level of wrongdoing, and so not cry out for the same retributive response. To see this, let's distinguish between first-instance and backup rightsbased duties (Shue, 2004, pp. 16-7; Waldron, 1993, p. 25). First-instance duties make up the initial line of defence for a right; they directly protect the interest. But when these first-instance duties are not performed, or do not have the intended effect, then further 'waves' (to use Waldron's term) of backup duties may be needed to remedy the situation.

As we will see, deontological considerations prioritise first-instance duties - especially first-instance negative duties not to harm. Because the failure to perform such duties is ceteris paribus a greater deontological wrong than failing to perform backup duties, that failure may warrant legal sanction and retributive response. However, the failure to perform (less stringent) backup duties need not demand an equivalent retributive response.

Consideration of guarantees and retribution thus recommend legal accountability for some duties, especially first-instance duties not to harm. However, legal accountability proves less necessary for backup duties, such as Bill's positive contributions to UNHCR.

\section{Right-holder Universality}

Right-holder universality can seem a sine qua non of rights-based duties. What could it mean, after all, to propose a human right that does not apply to every single human? But we need to distinguish two types of right-holder universality. First, duty-specific rightholder universality requires that, for every given rights-based duty held by a duty-bearer with respect to some right-holder, the duty-bearer holds that self-same duty with respect to every other person. Aneka's duty not to assault Ahmed was of this kind. She owed a duty of non-assault to Ahmed - and she owed the same duty to every other human.

Second, in regime-level right-holder universality, the overall regime of duties corresponding with a given right protects that right for every human. For instance, a rights theory (such as Locke's, (1947 [1690], II:60, pp. 182-3)) might hold that all children have rights to be supported and that the child's parents primarily bear these duties. (Other communitylevel solutions could ensure orphans' support.) In such a regime, every single child (Chitra) would have someone (e.g. Chitra's father, Cho) duty-bound to support that child. Usually, each child has two duty-bearers. While each duty-bearer's duties are not themselves right-holder universal - Cho owes his support to Chitra, not to every other child - the full regime of duties nevertheless supports every child.

Clearly, we need $d u t y$-specific right-holder universality for negative duties not to harm. If only half the local population bear duties prohibiting their harming Ahmed, then Ahmed's security suffers. Equally clearly, though, for other, welfare rights, the important quality is 
regime-level right-holder universality. Children do not need everyone to hold positive duties guaranteeing their support. They just need one duty-bearer willing and able to do so. As such, regime-level right-holder universality allows genuinely universal rights to be achieved through individually particularised positive duties.

\section{Duty-bearer Universality}

Consider again Cho's rights-based duties to his daughter Chitra. Such a duty only binds parents and caregivers. Because every human being does not bear such duties, they seem to fail duty-bearer universality. Other positive duties to contribute to welfare rights might also fail duty-bearer universality. The unemployed, for instance, will not contribute through taxation to others' education and health care.

Is this failure of duty-bearer universality an unacceptable feature of a rights-based duty? As a first response, we can refigure these sorts of duties in conditional terms. The conditions may refer to specific situations: 'If you have a child, you must support her.' Or they may refer to capacities: 'If you are prosperous, then you must contribute to children's education.' These conditional duties are duty-bearer universal: they apply to everyone. This means that every person can in principle be bound by the duty. Particular individuals are not required to shoulder duties that others in similar situations avoid.

This response hints at the fundamental issue: fairness in duty allocation. A rights regime must impose all its duties - including positive duties - fairly across all duty-bearers. Every duty-bearer, after all, enjoys their own rights and entitlements to equal treatment. Their lives and actions, in Kantian terms, cannot be used as a mere means to produce the resources required by others. Doubtless, controversy plagues the question of what this Kantian maxim involves - John Rawls and Robert Nozick, for example, give divergent interpretations. However, for our purposes the point is that it is this quality of fairness in duty allocation that is essential, and not the property of duty-bearer universality. Dutybearer universality may, in some cases, be a judicious method for ensuring a fair division of labour. In others, it may not. As such, duty-bearer universality is not per se an essential duty-property.

\section{Reciprocity}

Positive duties often do not possess reciprocity. For example, Chitra does not owe the same paternal duties of support to her father Cho that he owes to her (though she may owe Cho analogues of these when he becomes elderly). Rather, Chitra will owe those duties to her own children - and she may never have children. Is this failure of reciprocity a concern?

Effectively, the same points made above with respect to duty-bearer universality apply here. First, conditional duties are often reciprocal. Dinesh may have a duty to rescue drowning Daria, where Dinesh can easily rescue her at no risk to himself. But if their positions were reversed, Daria would owe the same duty to Dinesh.

Second, the fundamental issue to which reciprocity directs our attention is whether the rights-based duties are being fairly imposed on the duty recipient, and respecting of her rights. The direct reciprocity of the prohibition on assault that Aneka and Ahmed owe one 
another furnishes a vivid case of the fairness of this particular duty imposition. But fairness may arise in other ways. Contract theory, for example, provides one method of justifying duties where we invoke an abstracted reciprocity. Contract theory asks what would have been agreed from some special bargaining position, and this may not yield two concrete people in a particular situation, such as Chitra and Cho, owing symmetrical duties to one another. Ultimately, what matters is not direct reciprocity, but fairness in the allocation of the entire suite of rights-based duties - a property that might well apply to positive duties.

\section{Perfection}

Historically, many philosophers have thought rights can only give rise to perfect duties (Griffin, 2008, p. 96). Unlike imperfect duties, perfect duties countenance no latitude in when, how, where and towards whom they must be performed (Igneski, 2006). There seem to be good reasons for welding rights and perfect duties together. Rights-based perfect duties help to guarantee rights by concretising what duty-bearers can and cannot do. Additionally, perfection can contribute to fairness in duty allocation by ensuring that each duty-bearer's duties require the same actions as every other duty-bearer. In contrast, an open-ended obligation to achieve some objective might be more onerous for some duty-bearers than others. So too, perfection helps with deontology (as we will see) because it provides a clear point where Aneka completes her duty, and fulfils her responsibility to Ahmed. Open-ended imperfect duties might collapse into the maximising logic of utilitarianism, dissolving the distinction between what Aneka owes Ahmed and what others owe him. Finally, perfect duties are justiciable - courts of law can judge on whether they are performed.

These reasons suffice to demonstrate that, at least when it comes to protection from harm, every interest must be protected by perfect duties. When it comes to fashioning our life plans, reliance requires that we can predict what actions others might perform that will harm ourselves or our projects, rather than what goals they will pursue.

However, this does not mean that all rights-based duties must be perfect. Duty-bearers can be legally accountable for their performance of imperfect duties - consider laws requiring a 'duty of care'. So too, imperfect duties can include limits constraining how much one owes to others. For example, Bill may judge that after he gives a tithe of his net income to UNHCR he has fulfilled his obligations and may enjoy the rest of his earnings. And far from the plasticity of imperfect duties undermining fairness, the discretion duty-bearers wield over imperfect duties can empower them in judiciously apportioning the extent of their duties. Again, Bill's UNHCR duty furnishes an example, where he contributes an amount reflecting his current means.

Ultimately, the duty-properties of legal accountability, deontology and fairness in duty allocation may, in some contexts, require perfect duties. However, other cases may demand imperfect duties. Perfection per se is not an essential duty-property.

\section{Duty-consistency}

Duty-consistency ensures rights-based duties do not clash. This is important for two reasons. First, to the extent that rights offer guarantees to right-holders, such guarantees 
cannot be made with complete security if the duties constituting the rights conflict. In such a situation, something has to give, and one right must go unfulfilled. Second, clashing duties threaten duty-bearers with the invidious position where, no matter what they do, they will be wronging someone.

However, the spectre of clashing duties can be avoided by a process of specification: allowing the duties associated with one right to trump those relating to another right. This might be a general trumping; for example: 'negative duties not to harm an interest always trump positive duties to promote an interest.' Or the trumping may be context-specific: 'Dinesh's duty to save Daria from drowning trumps his duties to respect Ahmed's property right in his unused lifejacket.' In law and rights theory, this teasing out of which duty is prioritised can be performed either by reducing the scope of the right or its stringency (Moreso, 2012). In either fashion, by working out a hierarchy of duties applicable in particular contexts, this process of specification removes clashes - including those arising from positive duties.

Of course, specification must be done judiciously. The more the rights regime specifies Ahmed's property right in his lifejacket by inserting positive duties to use it to save drowning right-holders, the weaker the guarantees the regime offers Ahmed to his lifejacket. Guarantees remain, but, as Waldron (1993, p. 28) acknowledges, 'they may not be so strong or so unqualified as those we had in mind before we remembered the need to balance our own claims against those made by others'.

Specification of this sort can guarantee that duties accord with one another. It may be, though, that we should not aspire to complete duty-consistency. Judith Thomson (1990) argues we should accept clashes between rights-based duties, contending that rights only create obligations that demand respect, all other things being equal. In ordinary situations, Aneka violates a right if she fails to perform the required duties. In exceptional situations, however, such as when rights clash, Aneka may need to accede to another right's more urgent demands. If so, Aneka may permissibly infringe the right by not performing its duties (Thomson, 1990, p. 122). The infringed right need not disappear; Aneka may respond with compensation, apology and regret after failing to perform the right's duties, even though she acted correctly. If Thomson is right, we should countenance irresolvable conflicts between rights in exceptional situations, as such conflicts reflect the all-too-real dilemmas confronting actual duty-bearers.

\section{Deontology}

Recall that essential duty-properties protect the signature features of rights theories. Deontological properties prove vital in this respect because they immunise rights theories from powerful objections besetting consequentialist theories. For example, utilitarianism arguably demands too much of duty-bearers (not allowing them the prerogative to live their own lives) and licenses them to sacrifice the one for the many (not mandating constraints on how duty-bearers treat others). As Nozick (1974, p. 28) argues, even if a rights theory replaces 'happiness' with the 'non-violation of rights', if it retains the maximising logic of utilitarianism, it will allow (require!) Aneka to violate Ahmed's rights in order to reduce overall rights-violations. Such a result would be unwelcome, stripping rights theory of its flagship attractions. In order to avoid collapse into consequentialism, 
then, rights theories must retain the deontological duty-properties that ensure prerogatives for duty-bearers to live their lives, and impose constraints on how they treat right-holders.

What duty-properties secure these crucial outcomes? This is a vexing question, and I cannot pretend my short words here will provide the final answer to the ultimate relationship between rights theory and deontology. What I think I can do, though, is to present two properties - 'duty-bearer specificity' and 'relationship tracking' - that together secure these desired outcomes of prerogatives and constraints. If I am correct, that these properties do secure these outcomes, and correct again that positive duties can possess these properties, then this achieves our specific purpose here of showing how positive duties can accord with the signature features of rights theory. (Note we are here discussing only the duty's structural properties, not its ground. As Frances Kamm (1996, pp. 237-58) argues, it seems a mistake to assume we require these deontological properties because Aneka's moral focus must be grounded in her agency or relationships rather than based on the nature of Ahmed's rights.)

The first property, 'duty-bearer specificity', requires that, for some duty-bearer, Kylie, (a) Kylie's duties cease at some discrete point, and, (b) Kylie's duties are distinct from those of other duty-bearers (such as Kellen) and Kylie does not inherit with equal stringency the duties Kellen fails to perform. Without these qualities, the distinction between the duties of the two duty-bearers collapses. Protecting this distinction means Kylie can be prohibited from harming others even if doing so would prevent Kellen from (failing in his duties by) harming even more others. This is because Kylie's duty not to harm remains her own, and she does not simply inherit Kellen's responsibilities if he threatens to fail in them. Protecting the distinction between duty-bearers also prevents Kylie's duty-set swelling every time Kellen fails in his duties, allowing Kylie to retain the prerogative to pursue her own pursuits.

Earlier I distinguished between first-instance and backup duties. Now we must separate two types of backup duties. First, fault-triggered backup arises when another duty-bearer fails to perform his first-instance duties. For instance, duties to contribute to police institutions are fault-triggered backup duties emerging in response to the (anticipated) failure of criminals to perform their first-instance duties not to harm others. Second, supplementary backup duties are performed if the first-instance duty was performed but did not succeed in promoting the interest. For example, our first-instance duty to respect a person's right to food might be to respect her property rights in her farm. In a time of famine, however, this negative protection might prove insufficient, requiring supplementary backup duties of charitable giving. Duty-bearer specificity, then, demands that Kylie's first-instance duties are accorded moral priority over any fault-triggered backup duties she inherits when Kellen fails to perform his duties. This does not rule out such duties, but it does mean Kylie cannot inherit them with their original substance and stringency. In a word, rights-based duties are not transferable without cost.

The second element, 'relationship tracking', requires that rights-based duties track a duty-bearer's actual responsibility for a given situation, or relationship with the people in that situation. The more a duty-bearer caused a situation - especially any sort of harm the more that person is morally responsible for it. Equally, the more a person has an existing relationship with one of the right-holders (e.g. their partner, family member or employee), 
the more appropriate it is for that person to bear the rights-based duties. Cho's duties to his daughter Chitra are familiar deontological duties, tracking his existing relationship with her.

Deontological relations thus track existing relations - causal (i.e. harm-causing), familial, role-based and personal relations. We can see this prioritisation of existing relationships in 'connection theories' of responsibility, and it emerges intuitively in applied cases when we cast about for common-sense ways to allocate rights-based duties (Igneski, 2006, p. 447; Miller, 2007, pp. 81-109; Tan, 2006, pp. 96-102).

Having Kylie's duties track relationships means her duties focus on Kylie's actions rather than on outcomes more generally. Having Kylie's duties track causal relationships imposes action-constraints on Kylie by prohibiting her from personally causing rights-violations; Kylie's duties centre on what she causes, and not what Kellen causes. So too, having Kylie's duties track her personal, familial and professional relationships helps secure action-constraints because the people she must treat well are the ones within her everyday sphere of action. For example, corporate-executive-Kylie must attend to the rights of her employees and shareholders, rather than exploiting them in order to secure resources for promoting the rights of distant others.

Relationship tracking also helps sustain Kylie's prerogatives to live her life. Limiting the primary scope of Kylie's duties to her causal and personal relationships narrows the compass of her duties, constraining them to domains she knows and acts in. As well, since Kylie can exert control over what she causes, and over many of the relationships she enters, she can manage the scope of her duties. For instance, Kylie can choose not to become a parent if parental responsibilities would threaten her professional ambitions.

Relationship tracking need not prohibit duty-bearers from having deontological duties to strangers (below I consider Dinesh's duty to rescue Daria, a stranger, from drowning). However, relationship tracking ensures the first wave of duties imposed will track as closely as possible existing personal and causal relationships. People already in these relationships will prove the most appropriate candidates for the duties. But in a case where the performance of this first wave of duties fails to occur, or fails to protect the interest, fault-triggered and supplementary backup duties might be required. This next wave of duties, however, will be forced to call upon duty-bearers who are not equally connected to the right-holder or their situation. By reason of this increased distance (so to speak) between the duty-bearer and the situation, relationship tracking requires that these backup duties must not be as stringent as the first-instance ones.

In other words, we can think of duty-bearer specificity and relationship tracking as vindicating deontology's emphasis on one particular person's treatment of others. The property of duty-bearer specificity focuses on the 'one particular person' element. Aneka's most stringent duties focus on what she does, and not on what is done in general. This property prioritises first-instance duties over fault-triggered backup duties. The property of relationship tracking, on the other hand, focuses on 'treatment'. Those individuals most within Aneka's causal, social and personal spheres of action will be the appropriate right-holders of Aneka's duties. The further we move from these spheres, the less we will intuitively think that Aneka is 'treating' right-holders in one way or another. For example, if Bill fails to donate to the UNHCR, we might resist thinking he treated Buhjah improperly, even if 
his failure to contribute ultimately left Buhjah unprotected. By comparison, if Aneka fails to respect Ahmed's rights by assaulting him, we will all agree she treated him in a certain way (viz. badly). This quality thus prioritises first-instance duties over both supplementary and fault-triggered backup duties.

In summary, deontology requires that rights-based duties possess the properties of duty-bearer specificity and relationship tracking. Duty-bearer specificity requires that fault-triggered backup duties are less stringent than first-instance duties, while relationship tracking requires that first-instance duties are allocated on the basis of existing relationships, and that backup duties (being further removed from these relationships) are less stringent than first-instance duties. So long as they respect these requirements, positive duties cannot be rejected on deontological grounds. Thus, Bill might well bear backup positive duties to prevent Buhjah being assaulted, or to supplement others' efforts to provide for their children in famines. So long as these duties are not as stringent as his own duties not to assault others, or to provide for his own children's necessities, then the deontological quality of his duties is preserved.

\section{Directedness}

Rights-based duties require directedness for two reasons. First, directedness links with deontology. Whereas deontology prioritises our own proper treatment of others, directedness adds the distinctively rights-based feature that this proper treatment is owed to each right-holder. Second, the directedness of duties makes apology and remedy possible if the duties are not performed. As well as re-establishing the normative status of the right-holder, the prospect of remedies extends the ways the right can be guaranteed. Even if someone violates the right, the remedy might still return the victim to his prior position.

Rights-based positive duties can possess this one-to-one directedness. Cho owes his support to his child, Chitra. So too, consider a case where Dinesh is the only person who can rescue a stranger, Daria, from drowning, and can do so with no risk to himself. If Dinesh refuses to help Daria, then it seems arguable Dinesh has not merely done the wrong thing, but also that he has failed in the proper respect he owed to Daria (Igneski, 2006, pp. 447-9). So at least some positive duties can possess one-to-one directedness.

Other possible rights-based positive duties, however, will not. Consider a case where prosperous Erity dutifully contributes through her income tax to the education of local children. It seems implausible to say that Erity owes this duty to Etueni (a nearby child) even if - as it turns out - Etueni's education suffers if Erity dodges her tax obligations. Even in such a case, however, the community as a whole can owe Etueni an education, and a representative of the community could both apologise and (using communal funds) compensate Etueni for the community's failure to provide this education. The community would then pursue tax-shirking Erity as a separate matter. This many-to-one directedness allows apology and remedy, and responds to the fact that this proper treatment is owed to Etueni.

Are even less directed rights-based duties possible? Recall Bill's imperfect duty to donate to the UNHCR to protect refugees' rights. As it does not have a determinate right-holder, 
this duty cannot have one-to-one directedness. Indeed, it is doubtful the duty even has many-to-one directedness. The UNHCR simply cannot be responsible for every rightholder left unprotected.

Arguably, directedness is a necessary duty-property only for first-instance duties. As we have seen, on the basis of deontology it will be violations of first-instance duties, especially those prohibiting harms, that constitute the gravest wrongs and for which duty-bearers bear greatest responsibility. As such, failing these duties demands the re-establishment of the right-holder's status by the duty-bearer's apology and remedial action. Because later waves of duties will possess less deontological stringency, this need for directedness weakens with each iteration. This opens a space for Bill's imperfect duties to UNHCR as these are third-iteration backup duties. The duty-bearers violating their first-instance duties are of course those people actually assaulting the refugees. After this, locals - especially in local security and governance sectors - shoulder the first wave of backup duties. Next there may be international duty-bearers (e.g. host states and the United Nations) with their own duties of protection. Bill's duties may be the last piece in the puzzle, and the reasons for directedness become less urgent with each successive wave.

\section{Duty-right Sufficiency}

Henry Shue (2004, pp. 21-2) evocatively describes a situation when rights-protection fails because the tunnel dug under the channel from the rights side fails to meet the tunnel dug under the channel from the duties side. I will term the happy situation when the two tunnels meet 'duty-right sufficiency'. A rights regime achieves duty-right sufficiency when, in any situation where all the duty-bearers perform their full set of duties, this suffices to fill all the right-bearer's rights. Duty-supply meets rights-demand.

Duty-right sufficiency differs from the notion of 'guarantees' (where right-holders enjoy a reasonable expectation of their rights being fulfilled). We can picture duty-right sufficiency as in principle guarantees: if everyone performs their duties, this fulfils all rights. Guaranteeing something in principle contributes (but only contributes) to guaranteeing it in reality. It only contributes because people often fail to perform their duties.

But this final property of duty-right sufficiency threatens to pose the gravest impediment to positive duties, at least as they apply to welfare rights. In a situation with few available resources, how can duty-bearers fulfil positive rights to health care? Conceivably, of course, we could expropriate more resources from those doing well, or demand that all productive duty-bearers produce more, so that the health care can be assured. But duty-bearers are also right-holders, and we can only impose so far on them without threatening those rights. In such cases, we may simply not have enough to go around.

Must our rights regime uphold duty-right sufficiency? Agreed, it seems odd to think we could hold rights where we don't know who the duty-bearers are - or even if there are any duty-bearers at all. But as Griffin (2008, p. 109) points out, the common understanding of rights really does possess this feature: we can agree on the substance of a right without being sure of its duty-bearers, and we can assert that the right matters even as its duty-bearers shift and rearrange, disappear and re-emerge.

Perhaps you will insist this really will not do. A right without duty-bearers is hollow, you object, bereft of practical use. But is this so? Even in circumstances where a right has no 
duty-bearers, the right might prove not just useful, but momentous. Circumstances change, after all, and a right-holder might hold on in a dire situation precisely because he knows duty-bearers might emerge in time. Indeed, the right-holder herself can change those circumstances. Picture Buhjah, who fled a warzone to find sanctuary in a UN refugee camp - and in so doing moved from a battleground with few enough duty-bearers into a place where concrete duty-bearers abound (even, perhaps, ones like Bill, heroically wielding his bank card from the opposite side of the world).

If we accept that rights matter even in exceptional situations where there are no duty-bearers for them, then we can relax the requirement for duty-right sufficiency and adopt what might be termed the 'standing problem' position. This position accepts that, in circumstances of scarcity, duty-right sufficiency fails. Even if every duty-bearer performs all that can be asked of them, rights will not be adequately secured. However, this lack of fulfilment must be acknowledged by the society (and perhaps by humanity in general) as a standing problem. People are not getting what their dignity or personhood requires. As such, every person within the society has a conditional duty, in any situation where it does not violate their own rights, to work towards creating sufficient coordination, resources and institutions to fulfil these rights. The positive requirements of the welfare right cannot always trump other rights, but they remain a promissory note that must be filled as soon as scarcity is overcome.

Perhaps, resisting the above arguments, you remain wedded to duty-right sufficiency as an essential property. If so, consider the 'centres of pressure' view of rights. On this approach, we conceive each separate interest of each separate person as a figurative point in space, sitting alongside the other centre-points of all the other people's interests. Between each of these centre-points lies a boundary tracing where the rights-based protection of one interest finishes and the protection of another begins. For instance, the entitlements comprising Etueni's right to education must be balanced by Erity's rights of property and freedom of occupation (and vice versa). The boundary traced between these centre-points inscribes this point of balance. In straitened circumstances, little distance lies between the centre-points. Etueni's right to education can only extend a small way before impinging on Erity's rights to freedom of occupation and property. So the small circle of entitlement we can draw around Etueni's interest in education contains only the most basic resources, say, and perhaps negative protections against interfering with Etueni's pursuit of education by preventing others from teaching him. ${ }^{4}$ As the situation improves, however, the distance between each centre-point grows. As it does, the boundary inscribing each right progressively includes more space - more resources, and better entitlements to those resources. On this footing, even in straitened circumstances, duty-right sufficiency pertains. The relevant duties Erity (and others) owe to Etueni fully constitute his right to education - albeit that, surveyed from the perspective of better circumstances, Etueni's right appears enervated. Nevertheless, if prosperity improves, the net amount of Erity's tax dollars contributing to Etueni's education increases, and his quality of schooling improves.

Both these 'standing problem' and the 'centres of pressure' options possess their own merits. The standing problem position reminds us that each right has a minimum threshold. If Etueni's education fails to give an ordinary child any realistic hope of gainful employment later in life, or of understanding the complex world around him, then it seems obtuse 
to speak of his right being fulfilled. We can see this reflected in those rights in the UDHR declaring a minimum standard of treatment, such as the right to, 'a standard of living adequate for the health and well-being of himself and of his family' (Article 25). Equally though, it can fly in the face of reality to expect the same positive entitlements in difficult times as much as in prosperous ones. The centres of pressure position resonates in other UDHR provisions, such as those determining the right to social security in accordance with the organization and resources of each State' (Article 22).

Ultimately, while the standing problem position draws attention to an important question of adequacy, even if we insist that duty-right sufficiency remains an essential duty-property, the centres of pressure position allows positive duties to possess this feature.

This section has provided an account of essential duty-properties - properties which rights-based duties must possess if the rights theory aims to retain its signature features. Ultimately, I accorded very few of the starting ten candidates the status of essential duty-properties. Legal accountability, duty-bearer universality, reciprocity, perfection and consistency all facilitated deeper duty-properties of guarantees, fairness-in-duty-allocation, respect for duty-bearer's rights, and remedial and retributive aptness. I argued that positive duties could retain these properties. Some of the other initial candidates were modified in various ways: regime-level right-holder universality proved to be an appropriate version of right-holder universality for welfare rights, and many-to-one directedness a similarly applicable notion of directedness. The properties I associated with deontology (dutyholder specificity and relationship tracking) were required by all duties, but positive duties could be structured to accord with these.

If my arguments are sound, then a conceptual space opens for a wide array of positive duties based on liberty and welfare rights. These might be legal duties, such as Cho's obligations to his daughter and Erity's duties to contribute to Etueni's education. They might be perfect and directed duties, such as Dinesh's duty to rescue Daria from drowning. Or they might be imperfect and non-directed, such as Bill's donations to the UNHCR. Each of these types of positive duties, in different ways, can be implemented so as to accord with the essential duty-properties.

\section{Conclusion and Ways Forward}

A contextual picture of human rights emerges from the foregoing arguments. Every situation contains an irremovable core of negative duties respecting basic liberty rights. However, different situations shift the types of positive duties that each person's interest imposes on other duty-bearers. Across these shifts the interest itself does not change, but the duties securing the protection and promotion of that interest transform in response to different threats, different allocations of duties, different social institutions and coordinating mechanisms, different levels of security and prosperity, and so on. As we might put it, the 'core concept' of the right remains the same, but the 'specified right' containing the precise protections and responsibilities shifts from one context to another (Breakey, 2013). 
These positive duties can protect others' liberty rights or secure their welfare rights. The foregoing analysis uncovered no major structural differences between these two sorts of positive duties, though we did observe that positive duties to protect liberty rights must be fault-triggered backup duties, and so at least second-iteration duties. Also, because liberty rights are always guaranteed in principle, this means the challenges arising from duty-right sufficiency apply only to welfare rights.

Return now to the initial criticism levelled by O'Neill: rights without determinate obligations are null and void, even undefined. We can see now that answering O'Neill's challenge does not mean we need to allocate the required obligations in the abstract from our philosophical armchair, so to speak. What matters is that there is a process for ensuring the obligations have been determined by the time the rubber hits the road - by the time concrete people's rights are actually threatened. (We also must remember that the main challenge to securing rights arises not from the failure of rights theories to allocate duties, but rather from the failure of people to acknowledge those duties and to perform them. And every moral theory suffers that problem.)

In guiding this contextual filling out of duties, a rights regime can adopt several alternatives. A rights regime stressing deontological qualities might determine all rightsbased duties through appeal to prior causal, social and personal relationships, with a focus on avoiding harms to others.

Other rights regimes may allow more expansive construction of rights-based duties, allocating duties not based on pre-existing relationships. Joel Feinberg (1984, p. 67) described this approach in the context of duties of rescue. 'Each of us,' he observed, 'is capable of assigning to himself the unqualified moral duty - "Thou shalt not kill." On the other hand, we must in principle consult with our fellow citizens to determine a suitable rule, even a moral rule, governing our positive duty to rescue.' Now we might question whether we always need social construction to allocate a duty to rescue - if Dinesh is the only one able to save Daria, things seem straightforward enough. Allocations like this occur on the basis of capacity, where the person or institution most capable of fulfilling the duty (and at least cost) shoulders the responsibility for doing so (Griffin, 2008, p. 102; Miller, 2007 , p. 102). Naturally, such an approach must uphold fairness in duty allocation and the rights of duty-holders.

In less straightforward cases, Feinberg's point about social construction becomes harder to resist, and a rights regime may elect to mediate responsibility (Shue, 1988). Here, the state performs the positive actions to fulfill rights. Individual citizens increasingly 'cash out' their duties, allowing their contributions through taxation to shoulder the load of positively fulfilling others' rights.

A final possibility leaves at least some positive duties, especially backup duties such as Bill's duties to the UNHCR, imperfect, undetermined and unallocated. On this approach, we each take an open-ended, problem-solving and proactive stance towards advancing others' rights.

These modes are not incompatible, of course, and a rights regime might opt for pluralism, using each of these methods as one piece of a larger strategy. Indeed, rights might be used to frame the process by which the institutions of a rights-respecting community develop the policies, institutions and laws that move human rights from thin 
paper to thick action. Such a regime will focus on rights to vote and stakeholder representation in the social procedures determining the contextual duties.

To finish, we have seen that careful analysis of the required properties of rights-based duties does not foreclose the possibility of positive duties. True, opening a conceptual space for a duty does not justify its existence. Still less does this opening provide a fully-fledged theory of rights replete with an exhaustive list of human rights, principles of fairness in duty allocation, methods specifying each right's scope and stringency, and so on. Even bearing those important limitations in mind, if the foregoing arguments are sound we have no categorical reason for objecting to rights-based positive duties.

(Accepted: 14 April 2014)

\section{About the Author}

Hugh Breakey is a Postdoctoral Fellow at the Institute for Ethics, Governance and Law at Griffith University, Australia. He researches philosophical issues surrounding the nature of human rights (especially security, intellectual and property rights) and other topics in professional and applied ethics. In 2012, his first book, Intellectual Liberty: Natural Rights and Intellectual Property, was published by Ashgate. Hugh was also lead author on Enhancing Protection Capacity, a policy guide on the Protection of Civilians and the Responsibility to Protect. In 2013, he was elected President of the Australian Association for Professional and Applied Ethics. Hugh Breakey, Institute for Ethics, Governance and Law, Key Centre for Ethics, Law, Justice and Governance, Griffith University - Nathan Campus, 170 Kessels Road, Nathan, 4122 Queensland, Australia; email: h.breakey@griffith.edu.au

\section{Notes}

This article benefited from helpful comments on prior drafts by Paul Formosa and three anonymous reviewers for Political Studies.

1 For example, Feinberg (1984), Shue (1980), Shue (1988), Waldron (1993), Sen (2004). Griffin (2008, pp. 96-110) provides, by my reckoning, the most comprehensive analysis, but even he subsumes the distinct properties of guarantees, duty-consistency and duty-right sufficiency under one banner ('claimability') and does not consider properties of directedness, deontology, retributiveapt and remedial-apt.

2 For example, the 1966 International Covenant on Civil and Political Rights and International Covenant on Economic, Social and Cultural Rights. The Universal Declaration of Human Rights, in contradistinction, is a non-binding resolution of the General Assembly, and not a multilateral treaty.

3 While there are positive duties (e.g. for police officers), the maintenance of these institutions primarily requires liabilities (in Hohfeld's sense) to expropriation through taxation. However, many of the same concerns brought against positive duties apply to such liabilities.

4 This is, in fact, a reasonable snapshot of the right to education protected in the situations of armed conflict and occupation governed by the $4^{\text {th }}$ Geneva Convention, Articles 24, 50 and 94 .

\section{References}

Breakey, H. (2013) 'Who's Afraid of Property Rights? Rights as Core Concepts, Coherent, Prima Facie, Situated and Specified', Law and Philosophy, doi 10.1007/s10982-013-9190-5.

Feinberg, J. (1984) 'The Moral and Legal Responsibility of the Bad Samaritan', Criminal Justice Ethics, 3 (1), 56-69.

Frederick, D. (2010) 'Why Universal Welfare Rights are Impossible and What It Means', Politics, Philosophy and Economics, $9,428-45$.

Griffin, J. (2008) On Human Rights. Oxford: Oxford University Press.

Igneski, V. (2006) 'Perfect and Imperfect Duties to Aid', Social Theory and Practice, 32 (3), 439-66.

Kamm, F. (1996) Morality, Mortality, Volume II: Rights, Duties and Status. New York: Oxford University Press.

Locke, J. (1947 [1690]) Two Treatises of Government. New York: Hafner.

Miller, D. (2007) National Responsibility and Global Justice. Oxford: Oxford University Press.

Moreso, J. J. (2012) 'Ways of Solving Conflicts of Constitutional Rights: Proportionalism and Specificationism', Ratio Juris, 25 (1), 31-46.

Nozick, R. (1974) Anarchy, State and Utopia. Oxford: Basil Blackwell.

O'Neill, O. (2005) 'The Dark Side of Human Rights', International Affairs, 82 (2), 427-39.

O'Neill, O. (2010) 'Rights, Obligations, Priorities', Studies in Christian Ethics, 23 (2), 163-71.

Rawls, J. (1999) The Law of Peoples. Cambridge, MA: Harvard University Press.

Schmidtz, D. and Brennan, J. (2010) A Brief History of Liberty. Oxford: Wiley-Blackwell. 
Sen, A. (2004) 'Elements of a Theory of Human Rights', Philosophy and Public Affairs, 32 (4), 315-56.

Shue, H. (1980) Basic Rights: Subsistence, Affluence and US Foreign Policy. Princeton, NJ: Princeton University Press.

Shue, H. (1988) 'Mediating Duties', Ethics, 98, 687-704.

Shue, H. (2004) 'Limiting Sovereignty', in J. Welsh (ed.), Humanitarian Intervention and International Relations. Oxford: Oxford University Press, pp. 11-28.

Tan, K.-C. (2006) 'The Duty to Protect', in T. Nardin and M. Williams (eds), NOMOS XLVII: Humanitarian Intervention. New York: New York University, pp. 84-116.

Thomson, J. J. (1990) The Realm of Rights. Cambridge, MA: Harvard University Press.

Waldron, J. (1993) Liberal Rights. New York: Cambridge University Press. 